Published by the University of KwaZulu-Natal https://journals.ukzn.ac.za/index.php/JICBE

(C) Creative Commons With Attribution (CC-BY)

Journal of Inclusive cities and Built environment. Vol. 1 Issue 2

How to cite: Omirin and Falola 2021. Socio-Environmental Effects of Nigerian National Petroleum Corporation Depot, Apata, Ibadan on the Adjoining Neighbourhoods. Journal of Inclusive cities and Built environment. Vol. 1 Issue 2, Pg 55-69

\title{
SOCIO-ENVIRONMENTAL EFFECTS OF NIGERIAN NATIONAL PETROLEUM CORPORATION DEPOT, APATA, IBADAN ON THE ADJOINING NEIGHBOURHOODS
}

\author{
By O.J. Omirin and O.J. Falola
}

Published 25th October 2021

\begin{abstract}
Nigeria, one of the major crude oil producing countries in the world, transports petroleum products through pipelines to several oil depots located across the country from where it is trucked to end users. Activities within these depots are known to have impact on their immediate environment due to the nature of operations and the externalities generated. This paper therefore examined the socio-environmental effects of the Nigerian National Petroleum Depot, Apata, Ibadan on its immediate neighbourhood. A case study approach utilising primary and secondary data collection was adopted. Two hundred and five residential buildings and respondents were proportionally selected for sampling from four neighbourhoods within 500 metres radius of the facility. An environmental audit including ground water samples were randomly collected for testing and analysis from Adebisi stream and residential handdug wells. Findings revealed local access road incapacitation emanating from indiscriminate parking of fuel tankers and spiralling into constant traffic congestion on major roads. Desludging of fuel storage tanks (79.5\%) resulting into regular effluent discharge into the Adebisi stream and fume emission (62.6\%), were attested to by residents. Water quality analysis revealed a high concentration of lead (pb.0.06mg/l) above the maximum permissible limit of $(0.01 \mathrm{mg} / \mathrm{l})$ for potable water. Other detected metals, Cadmium (0.003mg/l), Copper (0.006mg/l) and Zinc (3.0 mg/l) were all within the appropriate recommended limits. The study recommended a periodic environmental audit and regular dialogue with stakeholders of the host communities for socio-environmental sustainability.
\end{abstract}

KEY WORDS Externalities, Environmental audit, Petroleum depot, Desludging crude oil, Ibadan.

O.J. Omirin and O.J. Falola - University of Ibadan, Nigeria

E-mail: olusegunfalola@gmail.com 


\section{INTRODUCTION}

The petroleum industry holds a major potential of hazards for the environment, as the pollution associated with its activities is dangerous and widespread. Pollution is associated with virtually all activities throughout all stages of oil and gas production, from exploratory activities to refining (Mariano, 2001). Wastewaters, gas emissions, solid waste and aerosols generated during drilling, production, refining (responsible for the most pollution), transportation and storage amount to over 800 different chemicals, among which, of course, prevail oil and petroleum products (Nemerow, 1995). The pollution manifests in form of intensification of the greenhouse effect, acid rain, poorer water quality and groundwater contamination (Abadie, 1999). The oil and gas industry may also contribute to biodiversity loss as well as to the destruction of unique ecosystems.

An oil depot has been defined as an industrial facility for storing oil and/or petrochemical products where these products are transported to end users or for further storage (Adewuyi et al. 2011; Adewuyi et al., 2012; Babatunde et al., 2014, Ogoko, 2014). Nigeria, one of the major crude oil producing countries in the world transports petroleum products through pipe lines to several oil depots located across the country from where it is being carried by truck-tankers to end users (Babatunde et al., 2014; Ogoko, 2014).

Petroleum products contain diverse components, such as hydrocarbons, heavy metals, antioxidants, dye additives, corrosive inhibitors, sulphur, naphthalene and some other inorganic components. These components increase the toxicity of petroleum products compared to crude oil (Albers 1995; Akporido, 2008; Uzoekwe et al., 2011; Adewuyi et al., 2012, Ogoko, 2014). Despite this, however, many companies in the oil business are not adopting pollution prevention practices (Mariano, 2007). Environmental policies of these companies are oriented towards compliance with rules established by environmental authorities that is hinged on a reactive approach to environmental management (Emilio Lèbre et al., 2009).

Oil exploration, refining, transportation and distribution have continually resulted in environmental degradation and destruction owing to neglect and limited concern to environmental management in the area (Eregha et al., 2009). This poses several environmental challenges to neighbouring human settlements. Transportation and distribution of petroleum products have often resulted in a multitude of social, environmental, and economic problems such as environmental pollution, occupational dislocation, rural-urban drift and poor human health (Elis 1994; Amadi et al., 1999; Ugbomeh 2007; and- Omajemite 2008). Accidents occur periodically during distribution of petroleum products. These may result from accidental discharges, deliberate or wilful acts of vandalization, neglect in carrying out proper maintenance and or even human error (Egbogah, 2006). Petroleum distribution at the depot may cause unrest because of ecological damage, environmental pollution and economic marginalization of the host communities. The environmental concerns should have been addressed by Environmental Impact Analysis (EIA), however, it was hardly undertaken prior to the approval of any project in Nigeria (DPR, 1999; Akintunde and Olajide, 2011). Violent protests by communities are the most eloquent testimonies of the resistance to environmental pollution as a result of petroleum related activities (Akintunde and Olajide, 2011).

Furthermore, traffic delay caused by petroleum trucks and sometimes road accidents involving these trucks has caused loss of property and human lives (Eme, 2011). Several working hours have been lost to protracted traffic congestion around the Nigerian National Petroleum Corporation (NNPC) Depot in Nigeria owing to truck haulage activities and sometimes road accident caused by petroleum tankers in Nigeria. The environmental impact of the petroleum depot and pipeline network had been researched (Majolagbe et al. 2011, Uzoekwe et al. 2011 and Adewuyi et al., 2012; Ogwu, 2014). However, socioenvironmental impact of NNPC depots has not been adequately documented in the literature. Based on the foregoing, this study examines the activities of NNPC petroleum depot, Apata, Ibadan, in order to determine the extent of impact of the depot's externalities and operations on the environmental, economic and social attributes to the adjoining communities. It analyses the effluent discharge from the petroleum depot and the effects on residents' livelihood.

\section{CONCEPTUAL FRAMEWORK AND LITERATURE REVIEW}

Measuring the extent of the impact of NNPC depot, Apata, Ibadan on its immediate neighbourhood is best considered with the Concept of Environment Impact Assessment (EIA). This is a process that identifies, predicts and describes in appropriate terms the benefits and negative values of a proposed development. "The Guideline for EIA procedure" was borne out of Federal Environmental Protection Agency decree of 1994 (FEPA, 1994). EIAcan be defined as a tool that evaluates the environmental effect of proposed actions in order to aid decision-making regarding the significant environmental consequences of projects or proposed development. It is a planning and management tool that can be used to promote sustainable development and aimed at providing decision makers with enough information on the consequence of projects especially those of potentially high impact, such as petroleum depots. Apart from setting guidelines for the protection of the environment, it also articulates the monitoring and enforcement of compliance with environmental measures (Akintunde and Olajide, 2011).

The petroleum sector is one of the sectors that generates the most controversy as far as the environment is concerned owing to the scale and extent 
of pollution that could occur (Ajakaiye, 2008). The atmospheric pollution and the impacts of the emissions on the health of the communities are now the subjects of liability issues in the international community (Olokesusi, 2005). Other related environmental concerns are emissions of green-house gases $\left(\mathrm{CO}_{2}\right.$, $\mathrm{NO}_{2}, \mathrm{SO}_{2}$ ); acidification; waste oil/water mixture, inadequately separated and discharged into the marine, riverine, and terrestrial environment; voluntary or involuntary damage; plume management at refineries, storage and distribution; and spill management (Ashton et al., 1999).

The acute and chronic health effects from exposure to gasoline and its additives have been documented to include cancer, central nervous system toxicity, and poisoning from additives (O'Rourke et al, 2003). The United States Environmental Protection Agency's Office of Compliance Enforcement (US EPAOCE) (2000) documented very high benzene levels in the air-levels 30 times those permitted in the US. These impacts tend to be concentrated particularly among lower income populations that live closer to service stations, refineries, and transfer or storage facilities (Epstein et al., 2002). There have been reported cases of petroleum products-related acute health effects such as coughing, burning eyes, headache, dizziness, and nausea and cases of severe asthma in the community, as well as cases of rare immune diseases, such as teenage lupus erythematous and childhood kidney cancer (UNEP, 2001).

Unfortunately, no national or international agencies currently collect or publish data on community health impacts from oil activities (World Bank, 2000). Data on mortalities from oil accidents are collected by different agencies depending on whether a worker or community member is killed and whether the accident is caused by a pipeline explosion, a refinery accident, or a tanker (UNEP, 2001). The best data currently available and even these are limited, cover workplace injuries and deaths in oil production and refining
(BLS. 2002; OSHA. 2003). However, virtually no data are available on chronic health impacts among communities living close to refineries. This is more worrisome as Doyle (1994:132) explains that "oil transport - by pipelines, railcar, or truck - generates an unknown and untabulated amount of waste, including tank bottom sludge, contaminated water from storage tanks, oil/water separator sludge, solvent degreasers, used-oil, contaminated product, product that does not meet specifications, lubricants, spent antifreeze, and clay filtration elements".

The end point of any development is human well-being which allows a healthy life in harmony with nature (Anyanwu, 2012). However, the careless nature of oil operations in Nigeria has made the environment increasingly uninhabitable (Aaron, 2006). The industry has created serious health and environmental pollution problems for the country in general and the host communities in particular. Since the discovery and drilling of oil in Nigeria, it is estimated that over 10 million barrels have been spilled (Ibeanu, 2000). Since the 1960s, large-scale oil spills have occurred almost every year (O'Rourke et al, 2003). There has been gradual environmental degradation with pollution of waters, destruction of aquaculture, vegetation and agricultural land during petroleum operations with no concerned and effective effort by the government and oil operators to control environmental problems associated with the industry (Ogwu, 2014). The environments are contaminated with these products through accidental spills and leakages during loading and offloading of tankers in the depots as well as washing of oil storage tanks and deliberate discharge of effluents (Ogwu, 2011; Oyeleke et al, 2016).

Unsustainable practices arising from activities in depot significantly contaminate soils ultimately pollute both surface and groundwater through leaching or infiltration. This constitutes serious health and environmental hazards to humans and aquatic resources (Majolagbe, 2011; Uzoekwe,
2011; Adewuyi, 2012). Water pollution occurs when pollutants are discharged directly or indirectly into the water bodies (Oyesiku et al., 2010; Oyeleke et al, 2016). When harmful chemical compounds used in the oil industry are not properly disposed of, there is the general belief, backed up by scientific evidence that, they cause pollution to surface and underground water, with dangerous consequences to human health, animals and underground organisms (Oyeleke et al., 2016). Spilled oil and petroleum products do seep gradually into sub soils and may pollute underground water and the soil with negative impact on environment and human.

\section{MATERIALS AND METHODS}

This study adopts a case study approach, using primary and secondary data sources. The secondary data used for this study were sourced through the review of books, journal articles as well annual report from the archive of the depot. The existing statutory guidelines from records of the Department of Petroleum Resources (DPR) based on environmental audit and environmental impact assessment was also consulted. Maps of the depot and its immediate neighbourhood within 500 metres radius were sought from Goggle Earth imagery.

Primary data was collected through the use of reconnaissance survey, interview, observation and structured questionnaires. The questionnaire was administered on the residence of the adjoining communities of NNPC depot at Apata. According to Yusuf (2001), it is usually not practicable to collect data from every unit of the relevant population of study thereby sampling is required. Therefore, systematic random sampling was adopted in administering the questionnaires.

Through reconnaissance and ground truthing, house count was conducted. Residential buildings that were within 500 metres radius, taken from the property boundary of the depot, were 
409. It is believed that residents that live within 500 metres of the facility would feel the impact most. Adopting a $50 \%$ sample size, a total of 409 residential buildings were selected, which were spread spatially across four communities - Adebisi Layout, Temidire, AjipeAllaha and Agbofieti, as shown in Table 1. All the buildings in the communities were numbered and simple random sampling method was used to select the respondents. In each building, a household was selected and questionnaire was administered on the household head.

The first unit was selected with the aid of a random number which was not more than the sampling interval. The sampling interval (409/205) equals $2.0(50 \%)$ and the first unit drawn was two (2). Therefore, the subsequent units were $(2+2=4) ;(4+2=6)$ and so on. The Probability Proportion to Size (PPS) was used to determine sample size for each community. The sample size, based on the PPS, is depicted in Table 1.

Table 1: Selected communities and Sample Size

\begin{tabular}{|l|l|l|l|}
\hline S/N & Neighbourhood & $\begin{array}{l}\text { No. of Residential } \\
\text { Buildings }\end{array}$ & $\begin{array}{l}\text { Sample Size with } \\
\text { PPS (50\%) }\end{array}$ \\
\hline 1 & Adebisi Layout & 224 & 112 \\
\hline 2 & Temidire & 90 & 45 \\
\hline 3 & AjipeAllah & 59 & 30 \\
\hline 4 & Agbofieti & 36 & 18 \\
\hline & Total & $\mathbf{4 0 9}$ & $\mathbf{2 0 5}$ \\
\hline
\end{tabular}

Source: Author's Field Survey, 2018

Oral and key informant interviews, open-ended individual conversation and direct observation, as well as personal observation were also used to collect appropriate information.

Standard procedure was followed for collecting and testing of water samples. The main objective is to determine the level of heavy metals - Cadmium, Copper, Chromium, Zinc and Lead - in Adebisi River and groundwater located in the vicinity of the depot and to compare with recommended standards. The sampling points designated as AW1 (7.3902716N, 3.8187823E) to GW2 (7.3969507N, 3.8114841E) were considered for sample collection. Water samples from Adebisi stream and two (2) groundwater samples were randomly collected from hand-dug wells around the NNPC depot with the aid of plastic bucket that has been previously washed and rinsed thoroughly with distilled water and suspended at one end of a rope. The sample containers were first washed three times with each water sample before collection and the containers were tightly covered immediately. A $3 \mathrm{ml}$ concentrated nitric acid was added to each sample to bring the water sample to $\mathrm{pH}<2$ and to reduce the microbial activities in order to maintain the integrity of the samples' transportation to the laboratory for analysis. Samples were taken during the month of December, 2016 (dry season) and there were no loading activities in the depot at that time. The management of the depot claimed that the association of petroleum marketers were on industrial action at that time.

The acidified water samples were digested with concentrated nitric acid prior to heavy metals ( $\mathrm{Cu}, \mathrm{Cd}, \mathrm{Cr}, \mathrm{Pb}$ and $\mathrm{Zn}$ ) analysis using Atomic Absorption Spectrophotometer (Bulk Scientific 210VGP). A blank sample was incorporated for every water samples analysed and duplicate analysis were carried out for all the samples. Analytical reagent (analaR) grade and commercial $\mathrm{BDH}$ stock standards were used for the instrument calibration according to manufacturer's instructions before analysis. All clean and prewashed plastic containers and glass wares used were soaked in $10 \%$ $(\mathrm{v} / \mathrm{v})$ nitric acid overnight and rinsed thoroughly with distilled water. A recovery study of the analytical procedure was carried out by spiking portions of previously analysed samples with mixed standards of Copper $(\mathrm{Cu})$, Lead $(\mathrm{Pb})$, Cadmium (Cd), Chromium (Cr) and Zinc $(\mathrm{Zn})$. These were then taken through the same analytical steps and the percentage recoveries determined. The minimum percentage recovery obtained for these metals was $91 \%$ for cadmium which validate the efficiency of extraction procedure and instrument used.

A known volume of extract was taken in a clean dry separating funnel and extracted three times with $25 \mathrm{~mm}$ hexane (aliphatic ionpolar) and diethylather for aromatic hydrocarbon-polar or a mixture of hexane and dichloromethane for total petroleum hydrocarbon, 50\% of hexane in acetane for PBCs. The aqueous layer was gradually removed leaving the organic layer in the funnel. The extract was transferred into a clean, dried and weighed stoppered $100 \mathrm{ml}$ volumetric flask and made to mask with the extracting solvent. The extract was evaporated over a nitrogen gas evaporator. The difference in the weight of the container with and without the extract given the amount of the total organic extract. 


\section{THE STUDY AREA}

The study was carried out in Ido local government area, which is located on latitudes $7^{\circ} 45 \mathrm{~N}, 7^{0} 15 \mathrm{~N}$ and longitudes $3^{\circ} 30 \mathrm{E}, 3^{\circ} 50 \mathrm{E}$ covers about $986 \mathrm{~km}^{2}$. The NNPC depot lies between latitude $07^{\circ} 23$ 'N and longitude $03^{\circ} 49$ 'E (See Fig. 1). The depot was established primarily to serve Oyo, Kwara and Osun states, with a capacity of 125.5 million litres, 148 million litres and 72.7 million litres for Automotive Gas Oil (AGO), Premium Motor Spirit (PMS), and Household Kerosene (HHK), respectively with 22 main tanks. The main purpose of the depot involves storage, supply and pumping. Ibadan depot supply petroleum products to terminal destination (llorin depot) through pipeline which can only receive and sell to non-terminal destination (marketers). These account for the relative advantage Apata depot enjoyed by having fuel at all times.

Loading hours in the depot was between $8.00 \mathrm{am}$ and $4.30 \mathrm{pm}$ every working day. The turn-around maintenance (TAM) of the storage tank was done every 3 years to boost the efficiency of the storage tanks. Each tank has a lock to prevent spill from the tank. Sludge that has accumulated overtime is usually removed during TAM. The process of neutralizing the water that enters the open tanks is called de-watering. Most time, the de-watering waste ended up in the nearby stream that flows through the neighbouring residential communities, such as Adebisi Layout. The depot has put some measures in place to prevent environmental disaster or pollution to impact the neighbourhood during TAM, by creating sludge tanks and evacuating of water after rainfall from open storage tanks. According to the management, strict adherence to safety rules and regulation within the loading and storage point is sacrosanct.

Figure 1: NNPC Depot in the Context of Ido LGA

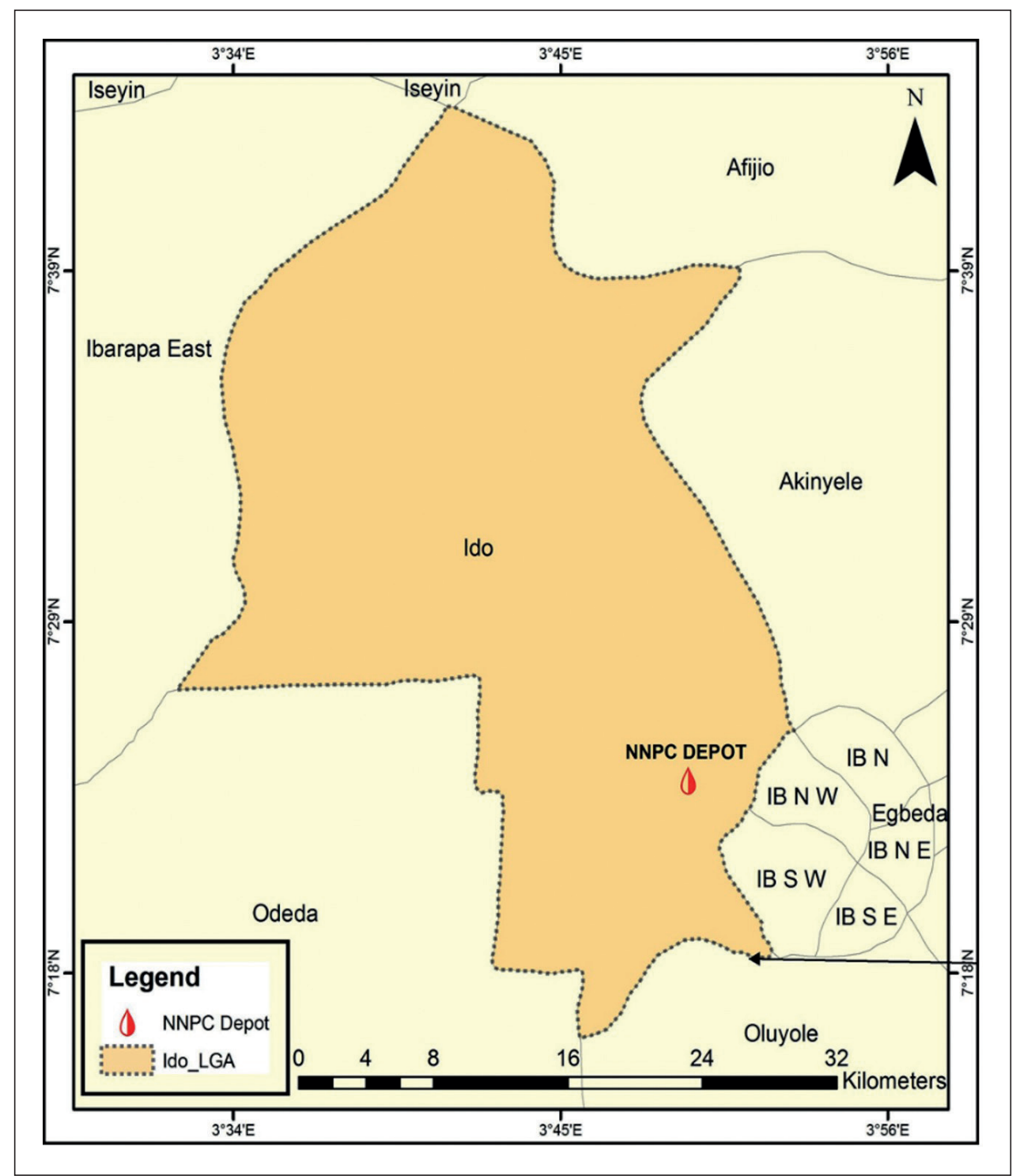

Source: Department of Urban and Regional Planning, University of Ibadan 


\section{RESULTS AND DISCUSSION}

\subsection{Analysis of Land Use in Close Proximity to Petroleum Depot}

Table 1 and Figure 2 show the inventory of the land use of the study area. Residential area has $50.1 \%$; mixed land uses is $21.5 \%$; commercial land uses is $12.5 \%$; circulation land uses is 8.7 ; religious centres land uses is $3.5 \%$ and institutional land uses (educational and financial) is 3.7. This implies that highest per cent of the land in the study area was used for residential purpose which exposes the residents to the risk of the externalities of the petroleum depot. It was also observed that some residential and educational land uses was very near to the depot which may affect the well-being of the occupants.

\section{Figure 2: Imagery of the Land Use within 500 metres Radius}

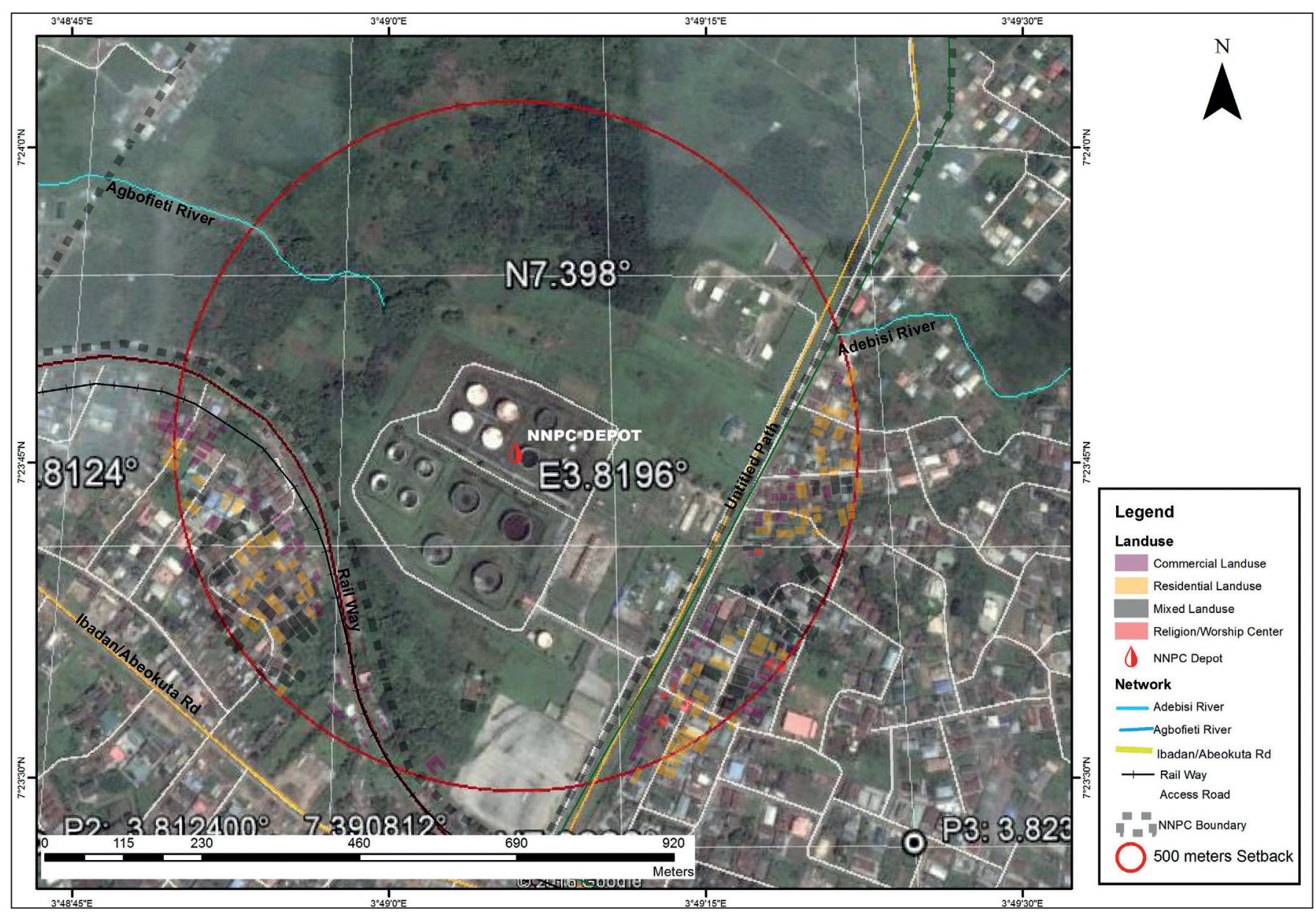

Source: ESRI, Digital Globe, Earthstar Geographics, 2016; Author's Field work, 2016

It was also observed that some land uses were altered such as residential and religious uses to accommodate retail and residential activities respectively because of the influence of the population of the study area. The depot which serves as focal point attracted population to the study area.

Also, the residents of the study area engaged more in retail activities because of the influence of the depot's operation and personnel (truck drivers, marketers and workers of the depot) transacting business in the neighbourhood. It was observed that drivers patronized the traders and restaurants located close to the NNPC petroleum depot. The nearness of some commercial activities such as restaurants also posed risk for the operation of depot. It was also observed that some financial institutions were located opposite the depot to facilitate the activities of the marketers and petroleum depot as a whole. 
Table 1: Land use Analysis of the Study Area

\begin{tabular}{|l|l|l|l|}
\hline Land use & No. of buildings & Land Area (M2) & Per cent \\
\hline Commercial & 70 & 12030 & 12.5 \\
\hline Mixed (residential and commercial) & 120 & 20623 & 21.5 \\
\hline Residential & 290 & 48120 & 50.1 \\
\hline Religion/Worship Centres & 15 & 3437 & 3.5 \\
\hline Institution (Education) & 10 & 2823 & 2.9 \\
\hline Financial Institution & 05 & 859 & 0.8 \\
\hline Circulation & - & 8108 & 8.7 \\
\hline Total & $\mathbf{5 1 0}$ & $\mathbf{9 6 0 0 0}$ & $\mathbf{1 0 0}$ \\
\hline
\end{tabular}

Source: Field work, 2018

\subsection{Socio Economic Characteristics of Respondents}

As shown in Table 2, 35.6\% of residents were male and $64.4 \%$ of residents were female. The modal age range was $31-40$ years accounting for about $49.7 \%$ of the respondents. This is the active population that the externalities of the depot could expose to a potential risk. The active age may engage in oil bunkering and harassment of depot pipeline and personnel if not well engaged. However, this active population represents potential source of cheap labour for casual (menial and contract) jobs in the depot.

Most of the residents were married (47.3\%) which implies that there would be natural increase with implication on the growth rate and population structure. This may affect the well-being and livelihood of the residents if adequate facilities and measures were not provided for the potential natural increase. Information in Table 2 also shows that $37 \%$ of the respondents had secondary and tertiary education which implies that the literacy level was high which projected them as informed about the impact of locating their building close to the petroleum depot. More so, since the depot was already built before the neighbouring communities were developed. From interview conducted, it was also observed that the residents were organized in the community organisation (CBO) in undertaking community obligation. During interview, the human relation officer of the depot said some residents of the neighbourhood were employed as a contract staff which attested to the level of literacy of the residents.

Table 2 indicated that $70.0 \%$ of the residents in the study area earned between $\mathbf{N} 26,000$ and $\mathbf{N} 60,000$ monthly while $23.4 \%$ earned above $\mathbf{N} 61,000$. Based on the $\mathbf{N} 20,000$ national minimum wage, this implies that residents of the study area were middle income earners which can sustain the high cost of living in the study area. During open-ended discussion with the residents, it was revealed that cost of living was relatively higher in the neighbourhood owing to proximity to the depot. 


\section{Table 2: Socioeconomic Characteristics of Respondents}

\begin{tabular}{|c|c|c|}
\hline Variables & No. of respondents & Percentage \\
\hline \multicolumn{3}{|l|}{ A. Gender } \\
\hline Male & 58 & 35.6 \\
\hline Female & 105 & 64.4 \\
\hline \multicolumn{3}{|l|}{ B. Age (years) } \\
\hline $18-30$ & 37 & 22.7 \\
\hline $31-40$ & 81 & 49.7 \\
\hline $41-60$ & 30 & 18.4 \\
\hline above 60 & 15 & 9.2 \\
\hline \multicolumn{3}{|l|}{ C. Marital status } \\
\hline Single & 45 & 22.2 \\
\hline Married & 96 & 47.3 \\
\hline Divorced & 22 & 13.5 \\
\hline \multicolumn{3}{|c|}{ D. Education Status } \\
\hline Non formal & 54 & 26.6 \\
\hline PSCE & 34 & 16.7 \\
\hline SSCE & 47 & 23.2 \\
\hline Tertiary & 28 & 13.8 \\
\hline \multicolumn{3}{|c|}{ E. Household Size } \\
\hline 3 persons & 30 & 18.4 \\
\hline 4 persons & 53 & 32.5 \\
\hline Above 4 & 80 & 49.1 \\
\hline \multicolumn{3}{|l|}{ F. Occupation } \\
\hline Farming & 33 & 20.2 \\
\hline Civil service & 62 & 38.0 \\
\hline Trading & 42 & 25.8 \\
\hline Artisan & 15 & 9.2 \\
\hline Informal sector & 11 & 6.7 \\
\hline \multicolumn{3}{|c|}{ G. Monthly Income } \\
\hline $18000-25000$ & 11 & 6.6 \\
\hline $26000-40000$ & 78 & 47.9 \\
\hline $41000-60000$ & 36 & 22.1 \\
\hline $61000-100000$ & 12 & 7.4 \\
\hline Above 100000 & 26 & 16.0 \\
\hline
\end{tabular}

Note: $N=163 ; 1 \$=N 320$

Source: Field work, 2018

\subsection{Effluent Discharge and the Effect on Residents' Livelihood}

Investigation revealed that, virtually all the respondents $(79.5 \%)$ attested to the discharge of effluent from the Depot, as shown in Table 3. This validate the observation of discharge of effluent into Adebisi stream and adjoining well in the study area. During field observation, the accumulated residual of the deposit could still be perceived around the neighbouring communities. The fact that the stream was also used for religious, domestic and commercial purposes posed greater danger to the users. The stream flows 
from the depot to join Odo-Ona River with its attendant problems.

Table 3 further indicated that most $(88.9 \%)$ of residents revealed that they were affected by the occurrence of effluent discharge; $6.1 \%$ were not affected by the occurrence of effluent discharge while $4.9 \%$ were undecided on the effect of effluent discharge on their livelihood. This finding is in tandem with Majolagbe (2011) and Adewuyi's (2012) studies which conclude that unsustainable practices arising from activities in depot constitutes serious health and environmental hazards to humans and aquatic resources. This implies that the well-water located around the stream Adebisi was contaminated by the occurrence of the discharge which affected its use for domestic purposes. As observed, the residents had to seek alternative means of water for domestic use with its cost implications. The depot applied some chemical to dry off the discharge and later closed some affected water-wells which also have its implication on daily domestic needs of the affected residents.

Apart from effluent discharge into nearby streams and wells, there were also cases of air pollution in the form of fumes released into the atmosphere from the depot. Table 3 revealed that $62.6 \%$ of the respondents often perceived fume of petroleum products in their communities while only $37.4 \%$ did not. This implies that, indeed air in the study area must have been polluted by the activities of the depot. This will expose the residents of the study area especially those residents nearer to the depot in Temidire and Adebisi community to respiratory diseases, such as asthma, and pneumonia. During field investigation in the surveyed communities, researchers' observation and experience reveals gasoline odour and fume around the neighbourhood. Although the study did not capture air quality, participant's experience during reconnaissance points at air pollution when compared to other communities the researchers have lived in Ibadan. Residents who have respiratory challenges would need to protect themselves by taking necessary precautions.

Cases of noise pollution were also documented by respondents. As shown in Table 3, $84.7 \%$ of the respondents claimed that they were affected by noise that emanated from industrial generators and tankers. The residents of Temidire and Adebisi communities were the most affected because of the nearness to the depot. In an interview with the safety officer about the noise emanating from the generating set, it was noted that the noise is insignificant because it is a silent generator. It only emanated noise when starting and this only last for few minutes before it synchronized. The officer discarded the notion of the noise pollution from the generating set. In another interview conducted with residents living close to the depot, however, it was revealed that the noise and vibrations from the generators causes serious disturbance. $\mathrm{He}$ added that they found it difficult to sleep at night when the generators were turned on overnight. Field observation established the high level of noise and vibration some households in Temidire Community experienced when the generator in turned on. It may cause ear defect if the generating set was not checked and noise proof applied.

Residents of the adjoining communities also identified the economic impact of the depot in their communities. Although, the majority $(61.9 \%)$ of the respondents claimed that the depot had negative impact on the local economy, more than one-third $(38.1 \%)$ of the respondents said they benefitted from the economic effect of the depot (Table 3). On the one hand, the commercial activities of some residents improved positively because of the patronage of staff, marketers and truck drivers that the depot attracted. On the other hand, those that complained about the economic effect of the depot identified high price of commodity due to the presence of the depot which affected the daily needs of the residents. In the same vein, the majority $(88.3 \%)$ of the respondents said the depot did not provide any direct employment to residents of the adjoining communities. Only $11.7 \%$ of the respondents said the depot provided direct employment to residents. In an interview with the human relation officer of the depot, it was revealed that that only few residents were employed as casual and contract staff as none of the core staff of the depot lived in the surveyed communities. This implies that the residents living in close proximity to the depot bore the environmental and economic costs associated with the depot activities with limited formal corresponding benefits (other than trading and commercial activities associated with informality). The NNPC depot, as a federal government establishment, followed rules before employment is offered which may resulted into agitation if active population of the residents of the study area were not engaged.

As evident in Table 3, most $(72.4 \%)$ of the respondents had no health issues as a result of exposure to effluent from the depot. Respondents that claimed to have effluent-induced health issues accounted for $27.6 \%$ of the respondents. This implies that, while there were evidences of health implication of effluent discharge, perceived effect of effluent discharge on health was low. Communities that were affected by effluent discharge from the depot took certain steps in response to the continuous discharge of effluent into their communities.

As shown in Table 3, more than twothird $(67.5 \%)$ of the respondents made formal complaints to the management the NNPC Depot about the incident of effluent discharge on Adebisi stream. The remaining $32.5 \%$ of the respondents did not take any step. This implies that the community took the initiative to control the menace by reporting the incident to apply necessary measures to reduce or clean off the spill. Also due to slow or no reaction of government, some residents refused to report but took personal preventive measure to prevent any effect. This poses danger to other inhabitants of the study area who were not informed about the occurrence. 


\section{Table 3: Effluent Discharge and the Effect on Residents}

\begin{tabular}{|c|c|c|}
\hline Variables & No. of respondents & Percentage \\
\hline \multicolumn{3}{|l|}{ A. Experience of effluent discharge } \\
\hline Discharge & 163 & 79.5 \\
\hline No discharge & 42 & 20.5 \\
\hline \multicolumn{3}{|l|}{ B. Respondents affected by effluent discharge } \\
\hline Affected & 145 & 88.9 \\
\hline Un-Affected & 10 & 6.10 \\
\hline Undecided & 8 & 4.90 \\
\hline \multicolumn{3}{|l|}{ C. Cases of fume emission } \\
\hline Noticed & 102 & 62.6 \\
\hline Unnoticed & 61 & 37.4 \\
\hline \multicolumn{3}{|l|}{ D. Noise pollution } \\
\hline Occurrence & 138 & 84.7 \\
\hline Non occurrence & 11 & 6.7 \\
\hline Undecided & 14 & 8.6 \\
\hline \multicolumn{3}{|l|}{ E. Community response to effluent discharge } \\
\hline Formal complaint to depot management & 110 & 67.5 \\
\hline No step taken & 53 & 32.5 \\
\hline \multicolumn{3}{|l|}{ F. Economic impact } \\
\hline Positive impact & 45 & 38.1 \\
\hline Negative impact & 118 & 61.9 \\
\hline \multicolumn{3}{|l|}{ G. Employment opportunity for Residents } \\
\hline Available & 19 & 11.7 \\
\hline Unavailable & 144 & 88.3 \\
\hline \multicolumn{3}{|l|}{ H. Health issues related to effluent discharge } \\
\hline Had health issues & 45 & 27.6 \\
\hline No health issues & 118 & 72.4 \\
\hline
\end{tabular}

Note: $N=163$

Source: Field work, 2018

The presence of the depot has facilitated the establishment of infrastructural facilities and social services in the neighbouring communities. Respondents identified the facilities/services that were established majorly to serve the demands from the depot's activities. As shown in Figure 2, relaxation facilities, such as restaurants, guest house, bear parlour and hotels were the commonest accounting for $74.8 \%$ of facilities provided. Other major facilities and services that were facilitated by the presence of the depot included commercial (68.1\%) and financial (banks) (71.2\%). The other services that had relatively lower influence from depot activities were tansportation (32.5\%), health (12.9), electicity supply (23.3\%) and educational facilities (8\%). These show that the deport has actually attracted physical and economic development into the adjoining communities. The operations of these facilities and services served as source of employment and income stream for many residents. This corroborates the findings of Alaba and Agbalajobi (2014) which revealed that the majority (77\%) of residents of depots' host communities agreed that the establishment of depots have improved socioeconomic activities within and outside the communities. 


\section{Figure 2: Community Facilities Facilitated by the Presence of the Depot}

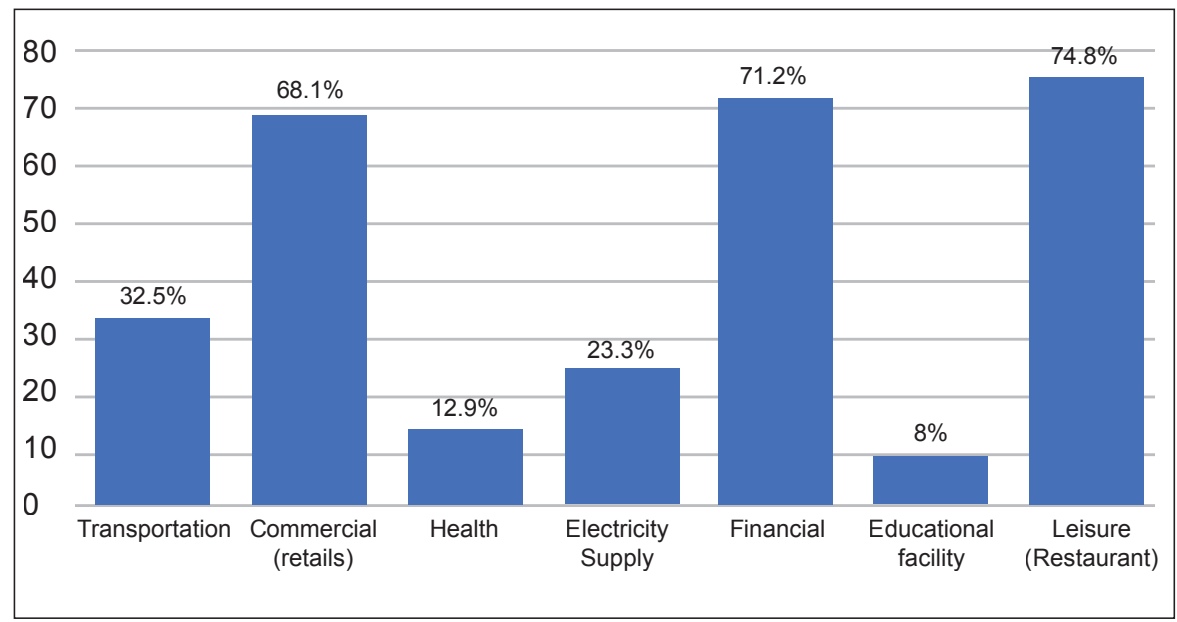

Source: Field work, 2018

\subsection{Impact of Tankers Activities on Local Roads and Traffic}

It was observed that the depot provided parking space and facilities for the trucks. Despite this, it was observed that truck tanker drivers still parked indiscriminately. As illustrated in Table 4, 61.3\% of the respondents attested to the occurrence of indiscriminate parking of truck tankers. Only about one-quarter (25.8\%) of the respondents said otherwise and $12.9 \%$ were undecided. This implies that truck drivers failed to observed traffic rules and regulations which exposes the residents to environmental and health risk. Some of the perceived reason for indiscriminate parking are park congestion (45\%) and nonchalant attitude of truck drivers (55\%). This implies that the drivers need to be warned and sanctioned accordingly to prevent unnecessary incident of truck explosion. The drivers need to be educated on the risk associated with indiscriminate parking on the road.

\section{Table 4: Occurrence of Indiscriminate Parking of Truck Tanker}

\begin{tabular}{|l|l|l|}
\hline Indiscriminate parking & Number of Respondents & Per cent \\
\hline Indiscriminate parking & 100 & 61.3 \\
\hline Proper parking & 42 & 25.8 \\
\hline Undecided & 21 & 12.9 \\
\hline Total & 163 & 100.0 \\
\hline
\end{tabular}

Source: Field work, 2018

During an interview with the management staff of the depot, it was noted that the parking facilities were meant for tankers that were scheduled to load petroleum products for a particular day. For security and safety purposes, it was revealed that all tankers were mandated to leave the depot premises on or before $6 \mathrm{pm}$ daily. One of the operations managers noted that the depot was usually opened on working days for tankers to load between $7 \mathrm{am}$ and $6 \mathrm{pm}$. With this arrangement, it is expected that tankers should not hindered traffic in the study area. However, there were evidences of road-side parking of tankers along major roads that serviced the depot. A resident of Adebisi Layout, who had lived in the neighbourhood for over 20 years corroborated the observation as follows:

"The tankers and their drivers have turned to menace for we residents of this area. If you have to leave your house very early in the morning, like 5:30 or 6 am, you will have to wait for as much as 30 minutes at the junction just because the tankers have queued on the road waiting for the depot to be opened. Sometimes, one can count as much as 50 trucks, many of which had arrived a night before, so as to beat arrival time and be among the first to enter the depot. The operations of the tanker drivers really need to be checked"- (Resident).

Another resident of the community expressed his concern:

"It gets worse during fuel scarcity when tanker drivers often parked their truck along the road for days, waiting for the time when fuel will be available for loading. In some cases, some tanker drivers had to sleep in their trucks for more than week, had their birth beside the road in the early hours, get dressed, eat and drink inside the truck. All these hindered free flow of traffic for residents of our communities". (Resident)

In another interview session conducted with a representative of Independent Petroleum Marketers of Nigeria (IPMAN), it was argued that there was no way the tankers will not have to queue because the depot will not be opened until 7 am and many of the tanker drivers would have arrived as early as $5 \mathrm{am}$. He added that they had no choice than to wait until the depot is opened for loading.

As evident in Table 5, most (80.4\%) of the respondents claimed that the access road that linked their communities, which also served as the major entrance to depot was in a bad condition. It was noted the heavy-duty tankers that ply the road on a daily basis often worsen the condition of the road. It was, however, acknowledged by the Adebisi Landlord/Tenants Association that the management of the depot often assisted in the repair and rehabilitation of the road. 
Table 5: Condition of Access Road

\begin{tabular}{|l|l|l|}
\hline Road Condition & $\begin{array}{l}\text { Number of } \\
\text { Respondents }\end{array}$ & Per cent \\
\hline Good & 32 & 19.6 \\
\hline Bad & 131 & 80.4 \\
\hline Total & 163 & 100.0 \\
\hline
\end{tabular}

Source: Field work 2018

Runoff from the depot was a major factor responsible for the deplorable condition of some access roads in the surveyed communities. About one-quarter $(24.5 \%)$ of the respondents claimed that their houses were often flooded by the run off from the depot. Consequently, it was observed that the access road linking Ajipe Allah and Agbofieti was unmotorable, only motorcycles ply the road with attendant risks. The residents faced hardship in moving from one neighbourhood to the other which also influenced cost of transportation. The affected community often contributed money to upgrade the road every dry season to make it accessible. This is, perhaps, the reason almost a half of the respondents identified erosion and poor drainage $(49.1 \%)$ and bad road $(50.9 \%)$ as the most pressing environmental problems militating against community development.

Furthermore, it was observed that a house was submerged at Adebisi Layout by flood water that emanated from the depot. The flood also destroyed the depot fence and no action has been taken to reconstruct it as at the time of survey. This implies that precaution needs to be taken by the management of the depot not to damage the environmental, economic and livelihood sustainability of the residents in the study area.

Although the human relation officer of NNPC depot said there is communication between the depot and the host community in addressing the problem but situation in the neighbourhood negated the assertion. There was no evidence of any collaboration between the depot and the communities in addressing the various challenges the depot posed to the communities. Community-based associations in the surveyed communities also denied any form of assistance from the management of the depot.

\subsection{Water Quality}

The result of heavy metals analyzed in river Adebisi and groundwater from the hand dug well in the vicinity of the oil depot indicated that the mean $\mathrm{Cu}$ contents in the water samples ranged between "not detected" and $0.019 \mathrm{mg} / \mathrm{l}$ with an overall mean of $0.00635 \mathrm{mg} / \mathrm{l}$. The mean $\mathrm{Cr}$ contents ranged from "not detected" to $0.005 \mathrm{mg} / \mathrm{l}$ (AW and GW1) with an overall mean of $0.0014 \mathrm{mg} / \mathrm{l}$. The mean Pb concentrations in the water sample had minimum concentration of $0.06 \mathrm{mg} / \mathrm{l}$ (GW1) and maximum concentration of $0.96 \mathrm{mg} / \mathrm{l}$ in groundwater GW1 with an overall mean of $0.45 \mathrm{mg} / \mathrm{l}$. The mean Zn contents in the water samples (AW and GW1) ranged between 0.018 $\mathrm{mg} / \mathrm{l}$ and $0.389 \mathrm{mg} / \mathrm{l}$ with overall mean of $0.042 \mathrm{mg} / \mathrm{l}$. Cd were not detected in the groundwater sampled.

The Copper and Zinc recorded in this study were within the recommended limits of regulatory agencies.. The concentrations of $\mathrm{Cu}, \mathrm{Cd}, \mathrm{Cr}$ and $\mathrm{Zn}$ were below the WHO and NIS maximum acceptable limits of $2.0 \mathrm{mg} / \mathrm{l}, 0.003 \mathrm{mg} / \mathrm{l}, 0.05 \mathrm{mg} / \mathrm{l}$ and 3.0 $\mathrm{mg} / \mathrm{l}$, respectively for drinking water in the water samples. In a study within similar setting, Abdus-Salam et al. (2017) reported concentrations of Copper that fell within permissible limits. This implies that high concentration of Copper is not always associated to eflluent discharge. This observation suggests no anthropogenic input of these metals from the activities in the depot. However, the Zinc concentration level was found to be above the WHOrecommennded minimum standard in a 2011 study carried out by Adewuyi et al within the vicinity of petroleum depot.

The levels of $\mathrm{Pb}$ were far above the World Health Organisation (WHO) and Nigeria Industrial Standard (NIS) maximum permissible limits of $0.01 \mathrm{mg} / \mathrm{l}$ for potable water. This elevation of lead content in surrounding groundwater might not be unconnected with the aged long adoption of lead compound such as lead tetra ethyl $(\mathrm{Pb}(\mathrm{C} 2 \mathrm{H} 5) 4)$ as anti-knock agent in petrol to ensure smooth burning in internal combustion engines and the presence of heavy metals in crude oil as natural constituents of the earth crust. The high $\mathrm{Pb}$ level may be attributed to spillage of petroleurom products arising from day-to-day activities taking place in the vicinity of petroleum depot. This high $\mathrm{Pb}$ concentration is of great concern as $\mathrm{Pb}$ is one of the heavy metals that has no known biological importance in living body and described toxic even in trace amount (Fernandes et al. 2008). Lead $\mathrm{Pb})$ reduces intelligence quotient in children and lead poisoning in adults can affect the peripheral and central nervous systems, the kidneys and liver failure, brain damage, headache, vomiting, loss of memory, gastrointestinal tract, anemia, nausea, insomnia, loss of appetite, irritability, convulsions, blood pressure, anorexia, both male and female reproduction, animal carcinogen, lung and stomach cancer (Needleman 1993; Steenland et al., 2000; Mortada et al., 2001; Jarup et al., 2003; Needleman 2004; and Zietz et al., 2007). The study on the effects of the petroleum depot effluents on the adjoining stream/ river by Abdus-Salam et al. (2017) showed similar results. It revealed high concentration levels of $\mathrm{Pb}, \mathrm{Cd}, \mathrm{Zn}, \mathrm{Ni}$, and $\mathrm{Cr}$ which were particularly high enough to cause public concerns. 


\section{CONCLUSION AND RECOMMENDATIONS}

This study provokes a new paradigm in the management and awareness of the environment to both the host communities and oil industry on one hand and the government as the regulating agency and relevant stakeholders on the other hand. The factors that affect the environment and socio-economic activities resulting to physical and mental health of the residents as a result of the operation of NNPC depot, Apata. These factors are environmental conditions, availability of infrastructural facilities, basic social economic activities and pollution.

Crude Oil is undoubtedly one of the most important commodities in the world. Without it, most vehicles cannot move, many homes cannot function, and national economies, especially in certain developing countries, would crumble. Unfortunately, with oil exploration and extraction practices comes an inherent risk of effluent discharge. Dangerous chemical waste, which must be stored or transported to prevent it from affecting the environment, is generated by oil processes and may be discharged. Environmental impacts on fragile ecosystems, cultural impacts on indigenous groups, health impacts on workers and communities, global climatic impacts, and impacts on poor communities living near pipelines and depots are critical issues that should be addressed. Also, the effect on the water and air quality around the neighbourhood as its affect domestic uses should be emphasized.

The people should be more involved and technically guided in the infrastructure planning process when necessary, and advocacy planning needs to be encouraged. Based on the forgoing, the residents of affected communities should be informed and enlightened about the environmental impact of the depot on their health and well-being. Advocacy planning should be used to make government responsible for the cost implication of the externalities of the depot on the study area. In addition to this, the NNPC depot management should engaged the leaders of the community on the subject matter. The management of NNPC depot should also be proactive in remediating the host community whenever there is effluent discharge. The management of the depot should inaugurate environmental audits of its operation and environmental sustainability approach should be adopted in its operations. Environmental planning and management (EPM) approach should be implemented as regards the minimizing the challenges, where all stakeholders would be involved, this must include community heads, marketers' association, youth representatives, NNPC depot management and the investors whether public or private to apply the concept of EPM, which allows the different stake holders to participate in the decision process and develop a shared perception.

\section{REFERENCES}

Aaron, K. K. 2006. Human Rights

Violation and Environmental

Degradation in the Niger-Delta:

In Porter, E. and Offord, B. (eds),

Activating Human Rights, Oxford,

Barne, New York

Abadie, E., 1999. Processos de Refinação (Refining Processes), $A$ Comprehensive and Detailed Text about Oil Refining Processes. Petrobras, Rio de Janeiro

Abdus-Salam, N., Ademola, O.S. and Bello, M.O. 2017. Assessment of the Impact of Petroleum Depot Effluents on a Nearby River Quality. European Scientific Journal, 13(36): 396-423. https://doi.org/10.19044/esj.2017. v13n36p396

Adewuyi G. O., Etchie O.T., Ademulegun O. T. 2011. Determination of Total Petroleum Hydrocarbons and Heavy Metals in Surface Water and Sediment of Ubeji River, Warri, Nigeria. Bioremediation, Biodiversity and Bioavailability. 5(1):46-51.
Adewuyi G. O., Olowu R. A. 2012.

Assessment of Oil and Grease, Total Petroleum Hydrocarbons and Some Heavy Metals in Surface and Groundwater Within the Vicinity of NNPC Oil Depot in Apata, Ibadan Metropolis, Nigeria. 13(1).

Adewuyi, G.O., Etchie, O.T. and Ademulegun, O.T. 2011. Determination of Total Petroleum Hydrocarbons and Heavy Metals in Surface Water and Sediment of Ubeji River, Warri, Nigeria. Bioremediation, Biodiversity and Bioavailability, 5(1), 46-51.

Ajakaiye, B.A. 2008. "Combating Oil Spill in Nigeria: Primary role and responsibility of the National Oil Spill Detection and Response Agency (NOSDRA)" Stakeholders' Consultative Workshop. August 4 - 6, 2008, Calabar, Nigeria.

Akintunde, M.A. and Olajide, A. 2011. Environmental Impact Assessment of Nigerian National

Akporido, S.O. 2008. An Assessments of Water, Sediment and Soil Pollution Arising from Crude Oil Spillages in the Vicinity of Esi River, Western Niger Delta. Ph.D. Thesis, Department Of Chemistry, University of Ibadan

Alaba, O.C. and Agbalajobi, S.A. 2014 Evaluation of Private Refineries and Depots in Distribution of Petroleum Products in Nigeria. International Journal of Engineering and Technology, 4 (2): 118-126.

Albers, P. H. 1995. Petroleum and Individual Polycyclic Aromatic Hydrocarbons. In: Handbook of Ecotoxicology. Lewis, London. 330-355.

Amadi, S.N. and Tamuno, S.O. 1999. Oil Exploration in Nigeria: Its SocioEconomic Impact on the Oil-Bearing Communities Tiber 3.1:1-6

Anyanwu Chukwudi U. 2012. The Oil industry and the Nigerian Environment, Department of Microbiology University of Nigeria Nsukka, Nigeria In 'IAIA12 Conference Proceedings' Energy Future The Role of Impact Assessment 32nd Annual Meeting of the International Association for Impact Assessmen, Centro de Congresso da Alfândega, Porto - Portugal (www.iaia.org) 
Ashton, N. J., S. Arnott and O. Douglas. 1999. The Human Ecosystems of the Niger Delta - An ERA Handbook. Environmental Rights Action, Lagos. 224pp.

Babatunde O. A, Oyewale A. O, Steve P. I. 2014. Bioavailable Trace Elements in Soils Around NNPC Oil Depot Jos, Nigeria. Journal of Environmental Science, Toxicology and Food Technology. 8(1):47-56.

Bisina, J. 2006. Environmental Degradation in the Niger-Delta (Unpublished).

BLS - Bur. Labor Stat. 2002. Fatal Occupational Injuries by Industry, 19962001. http://www.bls.gov/iif/oshwc/cfoi/ cftb0155. pdf

Department of Petroleum Resources (DPR) 1991. Environmental Guidelines and Standards for the Petroleum Industry, DPR, Lagos.

Doyle J. 1994. Crude Awakenings: The Oil Messing America: Wasting Energy Jobs and the Environment. Washington, DC: Friends Earth

Doyle J. 2002. Riding the Dragon: Royal Dutch Shell and the Fossil Fire. Boston: Environmental Health Fund.

Duruibe J. O, Ogwuegbu M.O.C. and Egwurugwu J. N. 2007. Heavy Metal Pollution and Human Biotoxic Effects. International Journal of Physical Sciences. 2(5):112-118.

Egbogah, E. 2006. 50 Years of Oil Production in Nigeria. Port Harcourt, Institute of Petroleum Studies,

Monograph No. 2. Harcourt: Amethyst \& Colleagues Publishers, p.3.

Elis, G. 1994. Shellin Nigeria: What Are the Issues? http://www.essentialaction. org/shell/issues.htm

Eme, O. I. 2011. Deregulation of the Downstream Oil Sector in Nigeria: History and Fallacies. Journal of Public Administration and Policy Research, 3.11:128-139

Emilio Lèbre La Rovere and Jacqueline Barboza Mariano. 2009. Environmental Impacts of the Oil Industry.
Encyclopedia of Life Support Systems (EOLSS) Federal University of Rio de Janeiro, Brazil

Epstein P.R, and Selber J. 2002. Oil: A Life Cycle Analysis of Its Health and Environmental Impacts. Boston: Center Health Global Environment, Harvard. Med. Sch.

Etkin DS. 1997. Oil Spills from Vessels (1960-1995): An International Historical Perspective. Cambridge, MA: Cutter Inf. Corp.

Federal Environment Protection Agency (1994) National Policy on the Environment. Federal Environmental Protection Agency, FEPA Abuja.

Fernandes C, Fontainhas- Fernendes A, Cabral D, Salgado M. A., 2008. Heavy Metals in Water, Sediment and Tissues of Liza Saliens from Esmoriz-Paramos Lagoon, Portugal. Environ. Monit. Assess. 136: 267-275.

Ibeanu, O. 2000. Oiling the Friction: Environmental Conflict Management in the Niger Delta, Nigeria. In Environmental Change \& Security Project Report, 6, 19-32.

IOSHIC - International Occupational Safety and Health Information Centre. 1999. Basics of Chemical Safety, International Labour Organization Conference, Geneva

Jarup L. 2003. Hazards of Heavy Metal Contamination. British Medical Bulletin.68:167-182.

Kaye P, Young H, O'Sullivan I. 2002. Metal Fume Fever: A Case Report and Review of the Literature. Emergency Medicine Journal. 19(3): 268-269.

Kharaka, Y. K. and Dorsey, N. S. 2005. Environmental Issues of Petroleum exploration and Production: Introduction Environmental Geosciences, 12.2: 61-63

Majolagbe A. O, Kasali A. A, Ghaniyu O.L. 2011. Quality Assessment of Groundwater in the Vicinity of Dumpsites in Ifo and Lagos, Southwestern Nigeria. Advances Appl. Sci. Research. 2(1): 289-298
Manzano, F. S. 2005. Supply Chain Practices in Petroleum Downstream. Published M.Sc. Thesis of Massachusetts Institute of Technology. Retrieved from http://dspace.mit.edu/ bitstream/handle/

Mariano, J. B., 2001. Impactos Ambientais do Refino de Petróleo (Environmental Impacts of Oil Refining), M.Sc. Thesis, PPE/COPPE/UFRJ, Rio de Janeiro

Mariano, J.B., 2007. Proposta de Metodologia de Avaliação de Impactos Ambientais para Estudos de Avaliação Ambiental Estratégica da Indústria de Petróleo e Gás Natural em Áreas Offshore (Proposal for a Methodology for Environmental Impact Assessment for Studies of Strategic Environmental Assessment for the Oil and Natural Gas Industry in Offshore Areas), D.Sc. Thesis, PPE/COPPE/UFRJ, Rio de Janeiro

Mortada W.I., Sobh M.A., El-Defrawy M.M. and Farahat S.E. 2001. Study of Lead Exposure from Automobile Exhaust as a Risk for Nephrotoxicity among Traffic Policemen. American Journal Nephrology. 21: 274-279.

Needleman H. 2004. Lead Poisoning. Annu. Rev. Med. 55: 209-22.

Needleman H. L. 1993. The Current Status of Childhood Low-Level Lead Toxicity. Neurotoxicology. 14: 161-166.

Nemerow, N. L., 1995. Zero Pollution for Industry, Many Information about Pollution Reducing in the Industry, 1 Ed. John Wiley \& Sons. New York

O'Rourke, Dara and Sarah Connolly 2003. Just Oil? The Distribution of Environmental and Social Impacts of Oil Production and Consumption. Annual Review. Environment Resources. 28: 587-61

Ogoko E.C. 2014. Evaluation of Polycyclic Aromatic Hydrocarbons, Total Petroleum Hydrocarbons and Some Heavy Metals in Soils of NNPC Oil Depot Aba Metropolis, Abia State, Nigeria. Journal of Environmental Science, Toxicology and Food Technology. 8(5): 21-27. 
Ogwu, F. A. 2014. Petroleum Pipelines, Spillages and the Environment of the Niger Delta Region of Nigeria Forum EJournal World Environment 4.3: 93100

Ojo M. O and Adebusuyi B. S. 1996. The State of the Nigerian Petroleum Industry: Performance, Problems and Outstanding Issues, CBN Economic and Financial Review vol 3

Olokesusi, F. (2005) Environmental Impact Analysis and the Challenge of Sustainable Development in the Oil Producing Communities. Abuja: NITP.

Omajemite, B. U. 2008. The Economic Dimensions of the Niger Delta Ethnic Conflicts: In Omotor et al (eds) Conflict Management and Peace Building in Africa. 2: 273

OSHA - Occup. Saf. Health Adm. 2003. OSHA Priorities: Oil and Gas Well Drilling and Servicing. http://www.osha. gov/oshinfo/priorities/oil.html

Oyeku O.T, and Eludoyin A.O. 2010. Heavy Metal Contamination of Groundwater Resources in a Nigerian Urban Settlement. African Journal of Environmental Science and Technology. 4(4): 201-214.

Olaoye, O.P. and Okparaocha, F.J. 2016. Assessment of Some Heavy Metals in Groundwater in the Vicinity of an Oil Depot in Nigeria. Department of Science Laboratory Technology, Federal College of Animal Health and Production Technology, Moor Plantation, Ibadan, Nigeria, American Chemical Science Journal 12(3): 1-7, ACSJ.22913

Petroleum Corporation (NNPC) Akwa Station. American Journal of Scientific and Industrial Research AJSIR. 2(4): 511-520

Rasmussen D.V. 1976. Characterization of Oil Spill by Capillary Column Gas Chromatography. Analytical. Chemistry. 48(11): 1536-1566.

Steenland K and Boffetta P. 2000. Lead and Cancer in Humans: Where Are We Now? American Journal of Industrial Medicine.38: 295-299.
Ugbomeh, B.A 2007. Oil Exploration and Exploitation: some lessons from Delta State. In Odemerho et al (eds) Delta State in Maps. An Occasional Publication series of the Department of Geography and Regional Planning, Delta State University Abraka. Pp.172

UN Environmental Program. 2001. UNEP Climate Change Information Kit http://www.unep.ch/conventions/ info/ccinfokit/Infokitpercent20percent202001.ht

United Nation Environmental

Programme (UNEP). 2011.

Environmental Assessment of Ogoni Land.ISBN:978-92-801-3130-9.

Retrieved from www.unep.org/nigeria.

United Nations Development

Programme (UNDP) 2006. Niger-Delta

Development Human Report.

US Environmental Protection Agency

Off. Compliance Enforcement (US EPAOCE). 2000. Profile of the Oil and Gas Extraction Industry. Washington DC: GPO

Uyigue, E. and Agho, M. 2007. Coping with Climate Change and Environmental Degradation in the Niger-Delta of South Nigeria. Community Research and Development Centre (CREDC), Benin.

Uzoekwe S.A, Oghosanine F.A., 2011. The effect of Refinery and Petrochemical Effluent on Water Quality of Ubeji Creek Warri, Southern Nigeria. Ethiopian Journal of Environmental Studies and Management. 4(2):107116.

WHO (World Health Organization). 2011. Guidelines for Drinking-Water Quality. 4th Ed, NLM Classification: WA 675, World Health Organization, Geneva, Switzerland;30, 74:33.

World Bank, 2000. Health and Environment. World Bank Draft Report, p. 1

Zabbey, N. 2004. Impacts of Extractive Industries on the Biodiversity in the Niger-Delta Region, Nigeria. Eleme. Centre for Environment, Human Rights and Development.
Zietz B. P, Lap J, and Suchenwirth R. 2007. Assessment and Management of Tap Water Lead Contamination in Lower Saxon, Germany. International Journal of Environmental Health Res. 17.6:407418. 
Notes 